INDEPENDENT JOURNAL OF MANAGEMENT \& PRODUCTION (IJM\&P)

http://www.ijmp.jor.br

V. 10, n. 5, September-October 2019

ISSN: 2236-269X

DOI: $10.14807 /$ ijmp.v10i5.925

\title{
ASSESSMENT OF BONDS UTILISATION IN THE NIGERIAN CONSTRUCTION INDUSTRY
}

\author{
Usman Muhammed \\ Federal University Of Technology Minna-Nigeria, Nigeria \\ E-mail: ussymamin4real@yahoo.com \\ Emmanuel Chidebere Eze \\ Federal University Of Technology Minna-Nigeria, Nigeria \\ E-mail: emmanueleze001@gmail.com \\ John Abel Tsado \\ Federal University Of Technology Minna-Nigeria, Nigeria \\ E-mail: gutsadoabelj@gmail.com \\ Blessing Okokun \\ Federal University Of Technology Minna-Nigeria, Nigeria \\ E-mail: blezy2003@yahoo.com \\ Submission: 12/08/2018 \\ Revision: $2 / 08 / 2019$ \\ Accept: 2/27/2019
}

\section{ABSTRACT}

Default by contractors in meeting the time and cost performance of a project is usually counterproductive. Considering safety from the high financial burden of construction projects, clients are compelled to seek a level of guarantee in bonds to safeguard them from financial problems and provide an incentive for proper and timely completion of the project by the contractor, thus, minimising failures and risks. Therefore, the study assessed the level of bond utilisation in the Nigerian construction industry, with a view to examining the benefits of its utilisation in construction projects. A survey method was adopted in which questionnaires were used to collect data from respondents. With a response rate of $45.30 \%$ (164 of 362 ), the collected data were analysed using descriptive and analytical scientific method. It was found that the level of bond utilisation in the construction contract is high, with a performance bond and Advance payment bond being the most commonly used construction bond types. 
INDEPENDENT JOURNAL OF MANAGEMENT \& PRODUCTION (IJM\&P)

http://www.ijmp.jor.br

V. 10, n. 5, September-October 2019

ISSN: 2236-269X

DOI: 10.14807/ijmp.v10i5.925

Assurance of performance and financial security are the major benefits of bond utilisation. The study recommends that there is a need for more enlightenment of construction participants on the various types of bond used in construction contracts.

Keywords: Bond, Construction Industry, Construction Professionals, Financial Experts, Insurance Experts, Nigeria

\section{INTRODUCTION}

The construction industry is the cornerstone of the socio-economic development of nations of the world. It drives infrastructural provisions such as roads, schools, hospitals and other basic facilities (SAIDU; SHAKANTU, 2016); and the industry is adjudged the leading sector in any country (ADEWUYI; ODESOLA, 2015).

Thus, the industry is responsible for the physical transformation and development of the environment (OKE at al., 2013). In spite of the enormous benefits of the construction activities, construction projects are facing some challenges from failures, which results to project abandonment, delay in project delivery, cost inflation, poor quality of work and a high initial cost of the project (OGUNSEMI; AJE, 2006). In order to guide against these challenges be-devilling the construction industry of Nigeria, bond was introduced (OJO, 2011; OKE et al., 2015).

A construction bond is an instrument introduced to protect and/or indemnify its recipients against such negative occurrence; and for its benefits to be fully enjoyed, there must be practical implementation and enforcement of the bonding provisions and/or conditions. (OKE et al., 2015). Although, bond in construction contract was seen as a mere formality in the course of negotiating contractual terms and conditions by both clients and contractors (OJO, 2011).

Bond is an essential feature of the construction industry, and the first known record of contract bond evolved from the Mesopotamian region around 2750BC and has been part of the construction industry (SWEET, 2000). Bond was addressed in the first known written legal code and the oldest surviving written surety contract, recognizing the need to protect the taxpayer from contractor's failure. Most standard form of building contact requires the provision of bonds by the main contractor to the project owner (MCLYNTRE; STRISACHEK, 2005). 
INDEPENDENT JOURNAL OF MANAGEMENT \& PRODUCTION (IJM\&P)

http://Www.ijmp.jor.br

V. 10, n. 5, September-October 2019

ISSN: 2236-269X

DOI: 10.14807/ijmp.v10i5.925

Contract bonds, used seriously in the construction industry are a guarantee from a surety company to the project owner (obligee) that the general contractor (principal) will stick firmly to the provisions of the contract (KANGRI; BARKHEET, 2001).

The bond system is essential in construction projects, commonly perceived to provide a level of financial protection and incentive for proper and timely performance of the project (HARRELL, 2003). However, in spite of the benefits of bonds, its usage has its own problems such as increased cost to the contractor and reduces the profitability of the project (MUHAMMED, 2012). The money that would have been used in improving the financial position, cash flow etc., of the contractor, is been used to obtain bonds to the client (HENRY; AMMAR, 2005).

Oke and Ogunmola (2014) assessed the effects of retention bond on the performance of construction projects executed by the Ministry of works in Ondo state, Nigerian. The study reported a significant relationship between retention bond and project cost and time performance. Hassan and Adnan (2018) assessed the problems and abuse of performance bond in the construction Industry of Malaysia and found that the lack of uniformity and inconsistency in the contents of guarantee/bond forms results from the one-sided interpretations found in the contracts.

Oke and Ogunsemi (2016) carried out a study aimed at examining the effect of stakeholders, project characteristics and bonding decision factors on the administration of construction bonding using structural equation modelling within Lagos and Ondo states; and found that these variables have an effect on the success of bonded construction projects.

In a similar but separate study, (OKE, 2016) evaluated the risks that are associated with bonded and unbonded projects with a view to ascertaining their effects on overall construction projects success. The study utilised data from construction participants in Lagos and Ondo states. The study revealed that financial soundness of the issuer also known as credit risk has a major effect on projects with bond while for projects without bond, liquidity risk requires the most attention.

It is obvious that among the few available studies on bonding especially in Nigeria, there is little or nonexistence of studies that were carried out in Abuja, the geographical area of this study. Thus, the need to assess the level of bonds utilisation 
INDEPENDENT JOURNAL OF MANAGEMENT \& PRODUCTION (IJM\&P)

http://Www.ijmp.jor.br

V. 10, n. 5, September-October 2019

ISSN: 2236-269X

DOI: 10.14807/ijmp.v10i5.925

and its benefits among the construction companies in Abuja. The aim of this study is to assess the level of bonds utilisation in the Nigerian construction industry. The specific objectives of this study are to assess the level of bond utilisation in construction projects and to examine the benefits of its utilisation in construction projects.

The outcome of this study will add to the body of existing knowledge available regarding bonds utilisation and management in the construction projects. In addition, the level of awareness of bond utilisation and benefits will improved be among construction participants and the industry in general.

\section{CONSTRUCTION BOND}

A construction bond is a written agreement in which one party (the surety) guarantees that a second party (the principal) will fulfil its obligations to a third party BOSWELL (2010). Bonds is a tripartite agreement between the surety, the project owner, and the contractor on the project. Kangari and Bakheet (2001) opined that even though the underwriting process of surety bonding is considered as a line of insurance; it has many similar characteristics to a bank lending process because the applicant, in either case, is being judged as a credit risk.

OKE et al. (2015) assert that contractor most often transfers the risk of contractor default to a surety company through the submittal of contract bonds. Bonds constitute a legal guarantee that the project will be completed as expected. In instances where a bonded contractor fails to perform, the bonding company will provide some form of restitution to the owner (OKE et al., 2015)

A construction bond also is known as contract bonds is usually undertaken by a bank or other financial institution and is aimed at making payment to the client/employer up to a stated aggregate amount (i.e. bond amount) in defined circumstances (NDEKUGRI; RYCROFT, 2009).

According to Huang (2008), construction contracts require contractors to furnish performance securities that serve as fundamental financial management tools for project owners to transfer contractor default risks to security providers. Were good practice is followed in the prequalification, selection and appointment of contractors and sub-contractors/suppliers, there may not be the need for bonds and guarantees utilisation (JACK et al., 2006). 
INDEPENDENT JOURNAL OF MANAGEMENT \& PRODUCTION (IJM\&P)

http://Www.ijmp.jor.br

V. 10, n. 5, September-October 2019

ISSN: 2236-269X

DOI: 10.14807/ijmp.v10i5.925

Bond provisions normally increase the cost and time of a project, this was confirmed by Oke et al. (2013) who observed a significant relationship between the cost of the bond and initial cost; final cost; cost overrun; the number of days to secure bond; initial time, final time and time overrun.

\subsection{Classification of Bonds}

Deng et al. (2004) pointed out that the major difference is whether or not there is any condition to be met before the obligee is entitled to claim the bond. Based on the bonds condition, bonds are generally classified into two main categories according to MICHAEL (2003), and they are conditional bond unconditional or on-demand bonds.

\section{a) Conditional Bonds}

Conditional bonds can be identified as that in which payment was made as conditional upon proof of breach of underlying contract (as opposed to a mere notice of a breach) by the contractor. Therefore, in practical terms, the conditional bonds are considered as a security for damages which the employer may recover in the action against the contractor (MALLESONS, 2003).

Conditional bond is also seen as a default bond. It is a contract guarantee whereby the surety accepts 'joint and several' responsibility for the performance of the contractor's obligations under the building contract. In this, the contractor remains primarily liable for his performance and not protected by the bond (SUPARDI et al., 2011).

Conditional bonds are more often seen in domestic construction contracts and usually provide that the guarantor will pay the bond amount to the employer provided that certain conditions have been fulfilled. Usually, such conditions would be the contractor's insolvency or breach of contract. This means that the employer will have to prove its loss before receiving any monies payable under the bond (TCYOUNG, 2017).

\section{b) Unconditional Bonds}

Unconditional bond or "on demand" bond differs from conditional bonds whereby the contractor has to pay the sum assured on the demand by the employer/client without any proof of default. The contractor is entitled to insist that the demand should be made in a form prescribed in the bond (MICHAEL, 2003). 
INDEPENDENT JOURNAL OF MANAGEMENT \& PRODUCTION (IJM\&P)

http://Www.ijmp.jor.br

V. 10, n. 5, September-October 2019

ISSN: 2236-269X

DOI: 10.14807/ijmp.v10i5.925

It is a covenant by the surety (usually a bank) to indemnify the employer following contractor's default, subject to stated terms and up to a sum commonly between $10 \%$ and $20 \%$ of the main contract sum (SUPARDI et al., 2011). In most circumstances, unconditional bonds are required when there was a sum of money for a specific purpose against the contractor, the contractor might enjoy the used of funds otherwise the employer/client be protected away and improves the cash flow. This application is more to the retention sum where the employer expects that he was entitled to call on the bond and receive payment immediately if any dispute arises in a contract (DANIEL, 2008).

Essentially, an unconditional bond is made subject to conditions such as; the production of an architect or engineer's certificate stating it's opinion that there is a breach of the contract and the amount stated in the demand is the appropriate compensation for the breach, authentication of the signature of the owner in the demand and authentication of the signature of the Architect or Engineer in the Certificate.

Furthermore condition to an unconditional bond arises where the contract provides conditions to the payment of the demand (for example, that the contractor is in breach and failed to remedy the breach within X-days after receiving notice from the owner requiring him to do so). This type of clause creates an obligation between the owner and contractor separate from the obligation between the owner and the issuer of the bond; this could lead to the owner being in breach of contract by calling on the apparently unconditional bond. To avoid this problem, it is in the owner's interest that the contract does not mention the bond or any related condition (MALLESONS, 2003).

\subsection{Types of Construction Bonds}

According to MEHMET et al. (2006), performance bonds and payment bonds are the common types of bonds available in construction contracts, and those that are rarely considered in construction contracts are maintenance bonds, supply bonds and completion bonds. The most common construction bonds in Nigeria are bid bond, performance bond, advance payment bond and retention bond (OJO, 2011). The common bonds types in the US construction industry is either payment or performance (HINCHEY, 1986). 
INDEPENDENT JOURNAL OF MANAGEMENT \& PRODUCTION (IJM\&P)

http://Www.ijmp.jor.br

V. 10, n. 5, September-October 2019

ISSN: 2236-269X

DOI: 10.14807/ijmp.v10i5.925

Bond Guarantee Group highlighted the types of bond to included; Performance Bond, Payment Bond, Bid Bond - Proposal Bond - Financial Security Bond, Warranty Bond - Maintenance Bond, Supply Bond, Completion Bond, Subdivision Bond Development Bond - Improvement Bond, Landscaping Bond, Service Contract Bond, Contract Bond - Construction Bond. GIWA-OSAGIE (2018) states that the various bonds use in international and local construction contracts are the tender bond, bid bond, advance payment or repayment guarantees, and performance bonds.

However, the focus of this study is on bid bond, performance bond, advance payment bond and retention bond, since they are what is common among construction contracts executed in Nigeria.

a) Bid Bonds - In this type of bond, the bidder (i.e. contractor and surety) usually agree to be firmly and jointly bound to pay a specified sum of money to the employer during the period of bid validity on the occurrence of certain events or conditions (GIWA-OSAGIE, 2018). According to Bond Guarantee Group, these bonds are usually written at $5 \%$ or $10 \%$ of the bid amount and are submitted along with the bid proposal. A bid bond simply shows that a contractor has been prequalified for a project and if the project is awarded to the contractor, the bid bond guarantees that the contractor will enter into a contract with the owner. If the contractor fails to enter into the contract, $5 \%$ or $10 \%$ may need to be paid to the owner as damages. Generally, there is no charge for this bond.

b) Performance bond/Payment bond - This is the final bond written when a contractor is awarded a project; and the bond guarantees nearly every term and condition in the contract. That is proper workmanship, completed on time, among others (Bond Guarantee Group). Whereas the payment bond guarantees that all employee, subcontractors, and suppliers have been paid. The bond guarantees the execution of the contract by the surety in the event that the contractor fails to fully perform the contract (GIWA-OSAGIE, 2018). This bond is usually taken out by the contractor, usually with a bank or insurance company (in return for payment of a premium) for the benefit and at the request of the employer, in stipulated maximum sum of liability and enforceable by the employer, in the event of the contractor's default, repudiation or insolvency (ROBINSON et al., 1996). 
INDEPENDENT JOURNAL OF MANAGEMENT \& PRODUCTION (IJM\&P)

http://Www.ijmp.jor.br

V. 10, n. 5, September-October 2019

ISSN: 2236-269X

DOI: 10.14807/ijmp.v10i5.925

A payment bond guarantees the owner that subcontractor's, labours and suppliers will be paid the monies that they are due from the principal, the owner is the obligee; the "beneficiaries" of the bond are the subcontractors and suppliers. Both the obligee and the beneficiaries may sue on the bond. An owner benefits indirectly from a payment bond in that the subcontractors and suppliers are assured of payment and will continue in performance. On a private project, the owner may also benefit by providing subcontractors and suppliers a substitute to mechanics liens, if the principal fails to pay the subcontractors or suppliers, they may collect from the principal or surety under the payment bond, up to the penal sum of the bond, payment bond is often less than the total amount of the prime contract and is intended to cover anticipated subcontractor and supplier costs (SWEET, 2000).

c) Advance Payment Bonds, according to GIWA-OSAGIE (2018), are bonds given by the surety after the pre-tender stage when the contract must have been awarded to the contractor or bidder. This bond ensure that an agreed percentage of the contract sum is paid in advance to the contractor on the strength of the surety's undertaking, or guarantee to refund such proportion of the said advance payment received from the employer representing the value of work not done in the event of the contractor failing to fulfil the terms of the contract.

d) Retention bond is a guarantee or requirement to secure a due performance which lies in the background as a reassurance to the client at an overall loss during defect liability period that he may otherwise face which will be cushioned, to the limit of the bond (MALLESONS, 2003). According to JCT "98" in clause 30:3 "the employer may retain a percentage of the value of work, materials and goods referred to the contract which is named in the appendix as percentage of clarified value retained, provided always that the sum of the amount so retained equals the amount named in the said appendix as limit of retention fund which is $5 \%$, limit of $10 \%$ of the contract sum as at the time of tender".

Retention fund is an amount that is due to the contractor which the client hold as a guarantee; should there be defects on the structure during defect liability period, these funds retained are to be used to make good such defects. Once the contractor feels that he has put right all the defects, complained upon by the client, he is entitled to press for the issuance of a "certificate of completion making good defects as this is a prerequisite for the release of the other moiety of the retention monies and must be 
INDEPENDENT JOURNAL OF MANAGEMENT \& PRODUCTION (IJM\&P)

http://www.ijmp.jor.br

V. 10, n. 5, September-October 2019

ISSN: 2236-269X

DOI: 10.14807/ijmp.v10i5.925

procured before final certificate is due (SWEET, 2000). A contractor may furnish a bond to the employer to secure an early release of retention money; if defects are then found, the employer will thus have a fund to call on for their rectification as especially when the contractor fails to carry out his duties to make good such defects. Moreover, the contractor's money's are no longer retained (MURDOCH; HUGHES, 2000).

\subsection{Benefits of Bonds}

The main purpose of a bond is to provide some financial security in the form of a cash sum payable by the surety for the contractor's failure to perform his obligations under a contract (GIWA-OSAGIE, 2018). The benefits of bond utilisation includes; It indicates that a contractor is capable of fulfilling the obligations of the contract, bonded projects are more likely to be completed than non-bonded projects by the contractor, the contractor or subcontractor bonding capacity could increase the chances of securing more projects, the contractor could get technical, financial or management assistance from the surety bond producer and underwriter, and in case of default by the contractor, the client is assured of contract fulfilment by the surety company (SFAA). Thus, Bonds are meant to provide financial security of the client/employer against the default by the contractor in completing contractual obligations (ENTRUSTY GROUP, 2005).

\section{RESEARCH METHODOLOGY}

The study covered the assessment of the perceptions of construction professionals, financial and insurance experts on the level of bonds utilisation in the Nigerian construction industry with a view to determining the benefits of bonds utilisation in construction. The respondents are professionals in both contracting and consulting organizations, banks and insurance companies, and construction owner's (Clients) for both public and private sectors located in Abuja.

The choice of Abuja was based on the premise that Abuja is the Administrative headquarters of the country with lots of construction firms having their head office or branches in the country's capital as confirmed by (AJE et al., 2015). In addition, there are a lot of construction projects being executed on a daily basis. Furthermore, most of the professional's bodies related construction works have either their head office or liaison office in Abuja. 
INDEPENDENT JOURNAL OF MANAGEMENT \& PRODUCTION (IJM\&P)

http://Www.ijmp.jor.br

V. 10, n. 5, September-October 2019

ISSN: 2236-269X

DOI: 10.14807/ijmp.v10i5.925

According to Saidu and Shakantu (2016), Abuja is one of the metropolitan cities in Nigeria with the highest population of construction and other sector professionals practising in either constructing or consulting, banking, insurance and manufacturing companies or firms. Financial and insurance experts were considered in the study because of the vital role they play in the issuance, insuring and administration of bonds for construction participants.

The quantitative research approach was adopted for the study, and wellstructured questionnaires were used to collect data on the perception of the various professionals regarding the level of bond utilisation in the Nigeria construction industry. The questionnaires were administered by the authors and through the help of trained field assistants who were properly briefed about the research topic and given the necessary information on how to administer the questionnaire.

The questionnaire was designed in two sections using information derived from the review of the related literature. Section A covered the general information of the target respondents. Information gathered from section A served as a quality check and verification of the data from the other part of the questionnaire. Section B covered questions on the benefits and level of bond utilisation.

The respondents were requested to rate the level of bond utilisation by construction firms. This was based on a 5-point Likert scale, where $1=$ very low, $2=$ low, $3=$ Average, $4=$ high, and $5=$ very high. The respondents were also, requested to rate the benefits bond utilisation in construction contracts. This was based on a 5point Likert scale, where 1 = Not Important; 2 = Slightly Important; 3 = Moderately Important; 4 = Important; 5 = Very Important.

A pilot survey was adopted to test the suitability and appropriateness of the questionnaire to meet the study objectives as suggested by (FELLOWS; LIU, 2008). Eighteen (8) of the draft questionnaire were randomly distributed to the selected construction professionals and academics and based on their feedback, the final draft was made.

A total of 362 questionnaires were randomly distributed to target respondents within the study area. 169 of the questionnaires were retrieved out of the 382 distributed. 5 were discarded as a result of incomplete responses. Thus, only 164 were fit for the analysis, which represents a $45.30 \%$ valid response rate. 
INDEPENDENT JOURNAL OF MANAGEMENT \& PRODUCTION (IJM\&P)

http://Www.ijmp.jor.br

V. 10, n. 5, September-October 2019

ISSN: 2236-269X

DOI: 10.14807/ijmp.v10i5.925

Akintoye (2000) suggested that a response rate of $20-30 \%$ is adequate for questionnaire surveys in construction management studies. Thus, $45.30 \%$ is adequate for this study.

Frequencies, percentages, and Relative importance index (RII) were used to analyse the collected data. Frequencies and percentages were used to analyse the general information of the respondents. Relative importance index was used to analyse the respondents' perception of the level of bond utilisation and benefits of bonds to the client. Relative Importance Index (RII) is represented in the formula;

$$
R I I=\frac{\sum\left(1 n_{1}+2 n_{2}+3 n_{3}+4 n_{4}+\ldots . n\left(n_{x}\right)\right)}{n\left(n_{1}+n_{2}+n_{3}+n_{4}+\ldots . n_{x}\right)}
$$

Where, $\mathrm{n}=$ the constant responding weighting given to each variable by the respondents, $\mathrm{N}=$ is the total number of respondents used in the analysis

The decision-rule for determining the level of awareness is based on the cutoff; that items with RII of " 0.81 to 1.00 are rated "very high (VH)"; 0.61 to 0.80 are rated "High $(\mathrm{H})$ "; 0.41 to 0.60 are rated "Moderate (M)"; 0.21 to 0.40 are rated "Low (L)"; and below 0.20 are rated "Very Low (VL)".

Furthermore, the reliability and internal consistency of the questionnaire was carried out using Cronbach's alpha test. This test measured the reliability of each of the field of the questionnaire and the mean of the entire fields of the same questionnaire. The acceptable value range of Cronbach alpha is between 0.0 and +1.0 and as the value tends toward 1 , the higher the degree of internal consistency.

The Cronbach alpha value for the variables is 0.878 and 0.912 , thereby implying that the questionnaire is credible and have a high degree of reliability. A research instrument is perfect as the value of the Cronbach alpha tends towards 1.0 (MOSER; KALTON, 1999). This analysis was carried out using statistical package for social science (SPSS) Version 20.

Table 1: Reliability statistics

\begin{tabular}{|c|c|c|c|c|c|}
\hline \multicolumn{6}{|c|}{ Case Processing Summary } \\
\hline & & $\mathrm{N}$ & $\%$ & & \\
\hline \multirow{3}{*}{ Case 1} & Valid & 164 & 100 & Cronbach's Alpha & 0.878 \\
\hline & Excluded $^{a}$ & 0 & 0 & $\mathrm{~N}$ of Items & 5 \\
\hline & Total & 164 & 100 & & \\
\hline \multirow{2}{*}{ Case 2} & Valid & 164 & 100 & Cronbach's Alpha & 0.912 \\
\hline & Excluded $^{a}$ & 0 & 0 & $\mathrm{~N}$ of Items & 15 \\
\hline
\end{tabular}


DOI: 10.14807/ijmp.v10i5.925

Total 164 100

a. Listwise deletion based on all variables in the procedure.

Case 1- Level of bond utilisation; Case 2 - Benefits of bond utilisation

\section{RESULTS AND DISCUSSION}

\subsection{General information of respondents}

The analysis of the general information of the respondents showed that, on the basis of their categories $12.2 \%(20)$ are contractors, $20.12 \%$ (33) are Quantity Surveyors, 12.8\% (21) are Architects, 17.68\% (29) are Engineers, $25.00 \%$ (41) are Bankers/insurance officers, and $12.2 \%$ are clients. In a nutshell, bank/insurance companies constituted a larger proportion of the respondents as they are the major providers of the bonds to the construction companies.

In terms of year of experience, $23.78 \%$ of the respondents have experience between 0 - 5 years, 33.54\% represent professionals with 6 - 10 years, $20.12 \%$ of the respondents are professionals with 11 - 15years of experience, $16.46 \%$ represent professionals with $16-20$, and finally $6.10 \%$ are professionals with 21 years and above experience.

The average year of experience is 9.5years. In a nutshell, it was inferred that the respondents experienced enough and information extracted from them could be relied upon. Academically, $47.56 \%$ of the respondents hold a Bachelor degree, while 23.78\%, 26.22\% and 2.44\% hold a Higher National Diploma, Master degree and Doctorate degree respectively. This shows that the respondents are academically qualified to give an informed response that could aid the achievement of the study aim.

Based on the class of bonds, the respondents are more familiar with the conditional bonds than the unconditional bonds. This is evident in their responses; (133) $81.10 \%$ of them are familiar with conditional bonds while (31) $18.90 \%$ are familiar with unconditional.

Furthermore, the analysis revealed that the common bond types used among construction participants are performance bond (32.32\%) and Advance payment bond $(37.20 \%)$, and this is followed by retention bond (15.24\%). This finding is agreement with MUHAMMED (2012) and OKE et al. (2015). According to These similar but separate studies, it was found that an advance payment bond and Performance bond are the most common types of bonds used in a construction contract in Nigeria. 
INDEPENDENT JOURNAL OF MANAGEMENT \& PRODUCTION (IJM\&P)

http://Www.ijmp.jor.br

V. 10, n. 5, September-October 2019

ISSN: 2236-269X

DOI: 10.14807/ijmp.v10i5.925

Table 2: General information of respondents

\begin{tabular}{|c|c|c|c|c|}
\hline Category & Classification & Freq. & $\%$ & Cum. \% \\
\hline \multirow[t]{7}{*}{ Categories of Respondents } & Contractors & 20 & 12.20 & 12.20 \\
\hline & Quantity surveyors & 33 & 20.12 & 32.32 \\
\hline & Architects & 21 & 12.80 & 45.12 \\
\hline & Engineers & 29 & 17.68 & 62.80 \\
\hline & Banks/insurance & 41 & 25.00 & 87.80 \\
\hline & Clients & 20 & 12.20 & 100.00 \\
\hline & TOTAL & 164 & 100.00 & \\
\hline \multirow[t]{6}{*}{ Years of experience } & $0-5$ years & 39 & 23.78 & 23.78 \\
\hline & $6-10$ years & 55 & 33.54 & 57.32 \\
\hline & $11-15$ years & 33 & 20.12 & 77.44 \\
\hline & $16-20$ years & 27 & 16.46 & 93.90 \\
\hline & 21 years and above & 10 & 6.10 & 100.00 \\
\hline & TOTAL (Av. Year = 9.5) & 164 & 100.00 & \\
\hline \multirow[t]{5}{*}{ Academic Qualification } & Higher National diploma & 39 & 23.78 & 23.78 \\
\hline & Bsc/B.Tech & 78 & 47.56 & 71.34 \\
\hline & Master degree & 43 & 26.22 & 97.56 \\
\hline & Doctorate degree & 4 & 2.44 & 100.00 \\
\hline & TOTAL & 164 & 100.00 & \\
\hline \multirow[t]{3}{*}{ Classes of Bonds } & Conditional bond & 133 & 81.10 & 81.10 \\
\hline & Unconditional bond & 31 & 18.90 & 100.00 \\
\hline & TOTAL & 164 & 100.00 & \\
\hline \multirow[t]{6}{*}{ Common Bond } & Bid bonds & 10 & 6.10 & 6.10 \\
\hline & Advance payment bond & 53 & 32.32 & 38.41 \\
\hline & Performance bond & 61 & 37.20 & 75.61 \\
\hline & Payment bond & 15 & 9.15 & 84.76 \\
\hline & Retention bond & 25 & 15.24 & 100.00 \\
\hline & TOTAL & 164 & 100.00 & \\
\hline
\end{tabular}

\subsection{Level of awareness of bonds utilisation}

The analysis of the respondent's perception of the level of bond utilisation is shown in Table 3. From the table it can be seen that based on the ranking of the respondents' perceptions, performance bond with $(\mathrm{RII}=0.856)$ is ranked $1 \mathrm{st}$, followed by advanced payment bond with $(\mathrm{RII}=0.815)$ and thirdly, retention bond with (RII= 0.790). With the value of the relative important index, it can be concluded that all the respondents are aware of the bond types used in the Nigerian construction industry, as they all have their RII values greater than 0.50 (50\%). Overall, the level of awareness of bond utilisation is $78.41 \%$, implying a high level of awareness since it 
INDEPENDENT JOURNAL OF MANAGEMENT \& PRODUCTION (IJM\&P)

http://Www.ijmp.jor.br

V. 10, n. 5, September-October 2019

ISSN: 2236-269X

DOI: 10.14807/ijmp.v10i5.925

fell into the cut-off point of 0.61 to 0.80 set for 'high' level. Thus, it is concluded that the level of bond utilisation in the Nigerian construction industry is high.

This result supports the finding of MUHAMMED (2012) who reported that the level of advance payment bond utilisation ranges between $61-80 \%$. The result of this study also contradicts some findings of OKE et al. (2015) and MUHAMMED (2012). IT was found that the level of utilisation of bid bond, performance bond, and retention bond ranges between $5 \%-60 \%$. This is in disagreement with the result as the least level of utilisation is in bid bond which is 0.690 (69\%) and this fell within the cut-off point for High usages. OKE et al. (2015) who reported that on the overall, the level of awareness of the bond assessed was very low; and retention bond had the highest value of awareness, followed by bid/tender bond, performance bond and advance payment bond. It was, however, found by OKE et al. (2015) that considering the significance and usage of bond; advance payment bond and performance bond are the most widely used and significant in the construction industry of Nigeria. The least used are a bid bond and retention bond.

Table 3: Level of awareness of bonds utilisation in the construction industry

\begin{tabular}{|c|c|c|c|c|c|c|c|c|c|}
\hline \multirow[b]{2}{*}{$\mathrm{S} / \mathrm{Nr}$} & \multirow[b]{2}{*}{ Type of bond } & \multicolumn{5}{|c|}{ Responses } & \multirow[b]{2}{*}{ Sum } & \multirow[b]{2}{*}{ RII } & \multirow[b]{2}{*}{ Rank } \\
\hline & & Very Low & Low & Average & High & Very High & & & \\
\hline 1 & Bid bonds & 17 & 36 & 12 & 54 & 45 & 566 & 0.690 & 5 \\
\hline 2 & Advance payment bond & 4 & 13 & 18 & 61 & 68 & 668 & 0.815 & 2 \\
\hline 3 & Performance bond & 2 & 10 & 9 & 62 & 81 & 702 & 0.856 & 1 \\
\hline 4 & Payment bond & 12 & 20 & 13 & 55 & 64 & 631 & 0.770 & 4 \\
\hline 5 & Retention bond & 5 & 21 & 15 & 59 & 64 & 648 & 0.790 & 3 \\
\hline & Average & & & & & & & $78.41 \%$ & \\
\hline
\end{tabular}

\subsection{Benefits of Bond Utilisation}

Table 4 shows that the result of the analysis of the respondents perceived the benefits of bond utilisation in the construction industry. From the table, Assurance of performance $(R I I=0.927)$, Financial security $(R I I=0.927)$, It makes the contractor have a sense of commitment $(\mathrm{RII}=0.918)$, Completion of work within the stipulated time and cost budget $(\mathrm{RII}=0.910)$, and Its guarantee that the contractor will meet its obligations according to the terms and condition agreed upon (RII = 0.899); are ranked 1st, 2nd, 3d, 4th and 5th respectively.

This finding supports the finding of OKE et al. (2015) who found that bonds ensure that contractors comply with conditions of the contract and also help to indemnify clients against default. According to The Surety \& Fidelity Association of America, financial security and assurance of performance are key among the 
INDEPENDENT JOURNAL OF MANAGEMENT \& PRODUCTION (IJM\&P)

http://Www.ijmp.jor.br

V. 10, n. 5, September-October 2019

ISSN: 2236-269X

DOI: 10.14807/ijmp.v10i5.925

importance of bonds. Bonds ensure financial security and ensure timely completion and within budget.

For example, according to Oke and Ogunmola (2014), a retention bond has a significant relationship with construction time and cost performance. This implies the possibilities of having project cost and time being overrun as a result of default in the works of the contractor if there no retention bond or at least any other bond type. Bond also guarantee financial backing and ensure rectification of defects (OKE, 2013).

It is observed that bond utilisation in construction contracts can assist to cushion the effects of poor performance, which results from inefficiencies of the construction teams, faulty materials and workmanship, financial incapacity, among other factors. This increases the risks of failure in projects time, cost, quality, and other performance parameters.

Oke (2013) confirmed that the use of retention bond and other types of bonds reduces the level of risks and problems related to the performance of construction projects. Entrusty Group (2005) pointed out that the bonds provided for construction projects are meant to create financial safety of the client/employer against the failure of the contractor to complete its contractual obligations

The least ranked benefits of bond utilisation in construction are It allows for proper monitoring $(\mathrm{RII}=0.865)$, In the event of liquidation/bankrupt of contractor, there will be a safety provision to both parties $(\mathrm{RII}=0.821)$, It saves the contractor from any obstacles $(\mathrm{RII}=0.767)$, Bid validity clearly protected $(\mathrm{RII}=0.705)$, and Create mutual responsibility and discipline $(\mathrm{RII}=0.649)$.

Regardless of the ranking of the variables, a critical examination of the relative importance index value of individual variables showed that they are highly beneficial in construction contracts. The RII value ranges from $0.927-0.649$ which fell in within the cut-off point of 0.61 to 0.80 set for 'high' benefits. Furthermore, on average, the $\mathrm{RII}=86.0 \%$. It is, therefore, concluded that bond utilisation in a construction contract is highly beneficial to the parties to the contract and in the construction industry.

Table 4: Benefits of bond utilisation in the construction industry

\begin{tabular}{clcc}
$\mathbf{S} / \mathbf{N r}$ & Benefits & RII & Rank \\
\hline 1 & Assurance of performance & 0.927 & 1 \\
2 & Completion of work within the stipulated time and cost budget & 0.910 & 4 \\
3 & Financial security & 0.927 & 1 \\
4 & It saves the contractor from any obstacles & 0.767 & 13 \\
5 & Increase the level of assurance of financial utilisation & 0.89 & 8 \\
6 & Bid validity clearly protected & 0.705 & 14 \\
& & &
\end{tabular}


7 It guaranteed that the contractor would meet its obligations according to the terms and condition agreed.

8 In a case of default from the contractor, the client can call back on the bond to guard against loss.

9 Transparency

10 It also enables the client to know the strength of the contractor's ability.

It makes the contractor have a sense of commitment.

In the event of liquidation/bankrupt of the contractor, there will be a safety provision to both parties.

13 It allows for proper monitoring.

Create mutual responsibility and discipline.

\section{CONCLUSION AND RECOMMENDATION}

Failure of Time and cost performance of construction projects is now commonplace in the most construction industry of the world. With contractors being blamed for much of the failures. Bonds are obtained to safeguard clients from the financial problems and provide an incentive for proper and timely completion of the project by the contractor to eliminate failures and risks. This study assessed the level of bond utilisation in the Nigerian construction industry, with a view at examining the benefits of its utilisation in construction projects.

Based on the findings, the study concludes that the level of bond utilisation in the construction contract is high, with a performance bond and Advance payment bond is the most common construction bond type. Also, Assurance of performance, Financial security, It makes the contractor feels a sense of commitment, Completion of work within the stipulated time and cost budget, and Its guarantee that the contractor will meet its obligations according to the terms and condition agreed upon are the most important benefits derived from bond utilisation in the construction industry.

Consequent upon the finding of this study, the following recommendation was put forward as strategies for better knowledge on effective utilisation of bonds in the Nigerian construction industry. This study found that some of the practitioners are lacking ideas or knowledge on the least utilized bonds such as Retention and Payment bonds; thus, to make bonds more effective in the Nigerian construction industry, the researchers recommend that practitioners need to be enlightened about all types bonds used in the construction contracts. Considering the importance of bond, there is a need for proper documentation of all issues relating to bonds contract.

More benefits of bond utilisation could be identified from a similar study carried out in other regions of the country. So, there I need for further studies in that direction. 
INDEPENDENT JOURNAL OF MANAGEMENT \& PRODUCTION (IJM\&P)

http://Www.ijmp.jor.br

V. 10, n. 5, September-October 2019

ISSN: 2236-269X

DOI: 10.14807/ijmp.v10i5.925

In addition, a similar study could be carried out in the oil and gas sector of the Country, especially at the Niger-delta region of Nigeria that is dominated by oil and gas companies. Bond utilisation and management in construction contracts of oil and gas companies could be assessed.

\section{REFERENCES}

ADEWUYI, T. O.; ODESOLA, I. A. (2015) Factors affecting material waste on construction sites in Nigeria. Journal of Engineering and Technology, v. 6, n.1, p. 82- 99

AJE, I. O.; MAKANJUOLA, S. A.; OLATUNJI, O. A (2015). Assessment of factors affecting bid-no-bid decision of construction contractors in Nigeria. In: OGUNSEMI, D. R.; AWODELE, O. A.; OKE, A. E. (Eds.), Proceedings of the 2nd Nigerian Institute of Quantity Surveyors Research Conference. Federal University of Technology, Akure, p. 529-536

AKINTOYE, A. (2000) analysis of factors influencing project cost estimating practice. Construction Management and Economics, 18, p. 77-89

BOND GUARANTEE GROUP, INC. Retrieved on (6th June 2018) from: http://www.bondguarantee.com/suretybond/contractbond.html

BOSWALL, R. G. (2010) Construction Bonds Guide. Clark Wilson LLP, Retrieved on (8 August, 2017) from

https://www.cwilson.com/app/uploads/2010/09/construction-bonding-guide.pdf.

DANIEL, A. (1998) Construction news, "Secure the right bond". London Daniel Atkinson

DENG, H.; DING, S.; TIAN, Q. (2004) Reasons underlying a mandatory high penalty construction contract bonding system. Journal of Construction Engineering and Management, v. 13, n. 1, p. 67-74

ENTRUSTY GROUP (2005). What is a performance bond, its purposes and implications? Retrieved on (10 $10^{\text {th }}$ June 2018 ) from http://entrusty.com/site/wpcontent/uploads/2012/08/what-is-performance-bond-its-purposes-andimplications..pd

FELLOWS, R. R.; LIU, A. (2008) Research Methods for Construction, 3rd Edition. Wiley- Blackwell Science, London

GIWA-OSAGIE, O. (2018) Nigeria: The Legal Nature of Bonds in Commercial Transactions in Nigeria. Retrieved on (21st November, 2018) from:

http://www.mondaq.com/Nigeria/x/756142/Securities/The+Legal+Nature+of+Bonds+i $\mathrm{n}+$ Commercial+Transactions+in+Nigeria

HARRELL, J. (2003) Contractor associations ask state to lower retainage. The Daily Reporter (Milwaukee), 10th September, 2003

HASSAN, A. A.; ADNAN, H. (2018) The problems and abuse of performance bond in the construction Industry. IOP Conference. Series: Earth and Environmental

Science, 117 , p. 1-7 
HENRY, A.O.; AMMAR, K. (2005) An evaluation of contractors' satisfaction with payment terms influencing construction cash flow. Journal of Financial Management of Property and Construction, v.10, n.3, p.171-180, https://doi.org/10.1108/13664380580001074

HINCHEY, J. W. (1986) Payment and performance bond coverages and claims. The Arbitration Journal, v. 14, n. 2, p. 25-33

HUANG, Y. (2008) the pricing of conditional performance guarantees with risky collateral, Construction Management and Economics, v. 26, p.967 - 978.

JACK, R.; SIMON, B.; PHIL, G. (2006) Contract Practice Procedures. (4 Ed.), Oxford, Butterworth-Heinemann Publishers

KANGARI, R.; BAKHEET, M. (2001) Construction surety bonding. Journal of Construction Engineering and Management, v. 127, n. 3, p. 232-238.

MALLESSON, S. J. (2003) Performance bonds; Asian project construction update. Available in http//:www.mallesons.com.

MCLYNTRE, M.; STRISACHEK, D. (2005) Surety bonding in today's construction market changing Lines for contractor's bankers \& sureties. RMA Journal.

Available in http://www.findarticles.com \& http://sio/org/index/html.

MEHMET, E. B.; QINGBIN, C.; MAKARAND, H.; ISSAM, M. (2006). Warranty bonds from the perspective of surety companies. Journal of Construction Engineering and Management, v. 34, p. 333-337

MICHAEL, T. (2003) Understanding bonds and guarantees provision in construction contracts. Available in http://www.naspb.org/information@surety.org.

MOSER, C. A.; KALTON, G. (1999) Survey Methods in Social Investigation, 2nd Edition. Gower Publishing Company Ltd, Aldershot

MUHAMMED (2012) An appraisal of bonds' utilization in Nigerian construction industry (a case study of Abuja). Unpublished dissertation (BSc in Quantity surveying), Federal University of Technology Minna, Nigeria.

MURDOCH, J.; HUGHES, W. (2000) Construction contracts law and management. 2nd edition, Kath Reynolds London.

NDEKUGRI, I.; RYCROFT, M. (2009) the JCT 05 Standard Building Contract Law and Administration, (2nd ed.), United Kingdom, Butterworth-Heinemann Publisher

OGUNSEMI, D. R.; AJE, I.O. (2006) A model for contractor selection in Nigeria.

Journal of Financial Management of Property and Construction, v.11, n.1, p. 3344

OJO, A. E. (2011). Why do clients require construction bonds? Construction

Connects, OJ Connects Resources, v.1, p.1- 4

OKE, A. (2016) Comparative analysis of the impacts of risks on bonded and unbonded construction projects. Engineering \& the Built Environment Journal. Retrieved on (8 August 2018) from: http://hdl.handle.net/10210/223633

OKE, A. E. (2013) Benefits and level of using retention bond for construction projects in nigeria. International Journal of Architecture, Engineering and Construction, v.2, n.2, p. $98-105$ 
OKE, A. E.; OGUNSEMI, D. R. (2016) Structural equation modelling of construction bond administration. Journal of Financial Management of Property and Construction, v. 21, n. 3, p. 192-211.

OKE, A.; OGUNSEMI, D.; OGUNLANA, S.; AJE, O. (2015) An overview of usage and management of construction bonds in Nigeria. In: ALUKO, B.T., ODEYINKA, H.A., AMOLE, O.O., ADEMULEYA, B. A. \& DARAMOLA, O.P (Eds.). Proceedings of Environmental design and management international conference, Obafemi Awolowo University,lle-lfe, Osun State, p. 183-192.

OKE, A.; OGUNMOLA, P. (2014) Retention bond and performance of construction projects in Nigeria. Journal of Construction Project Management and Innovation, v. 4, n. 1, p, 721-733.

OKE, A.E.; OGUNSEMI, D. R.; AJE, I. O.; OGUNDIMU, A. F. (2013). Effect of Bid Bond on Construction Project Performance in Nigeria. In: Laryea, S. \& Agyepong, S.A. (Eds), Proceedings of the West Africa Built Environment Research (WABER) Conference 12-14 August 2013, Accra, Ghana, p. 407-418.

ROBINSON N. M.; LAVERS, A.P.; TAN, G.K.H.; CHAN, R. (1996) Construction law in Singapore and Malaysia. 2nd edition Singapore; Butterworth Asia.

SAIDU, I.; SHAKANTU, W. M. (2016) The contributions of material waste to projectcost overrun in Abuja, Nigeria. Acta Structilia, v. 23, n.1, p. 99-113

SUPARDI, A.; ADNAN, H.; YAAKOB, J. (2011) Legal comparison between conditional and unconditional on performance bond in Malaysian construction contract. International Surveying Research Journal (ISRJ), v. 1, n. 1, p. 45-55

SWEET, J. (2002) legal aspect of Architecture, engineering and the construction process. $6^{\text {th }}$ Ed. United states of America; Brooks/ Cole publishing company.

TCYOUNG, (2017) Conditional performance bonds $v$ on demand performance bonds. Retrieved on (8th August 2018) from:

https://www.tcyoung.co.uk/blog/2017/commercial/conditional-bonds-performancebonds

The surety \& Fidelity Association of America, SFAA. The importance of surety bonds in construction. Available on: https://suretyinfo.org/?wpfb_dl=149 